\title{
Decision Support System for flood management in Batang Arau river basin
}

\author{
Nurhamidah Nurhamidah ${ }^{1 *}$, Ahmad $\mathrm{Junaidi}^{1}$, and Arraufi Hasyim $\mathrm{Nz}^{1}$ \\ ${ }^{1}$ Departement of Civil Engineering, Faculty of Engineering, University of Andalas, Padang.
}

\begin{abstract}
Flood is one of the most vulnerable disasters in Indonesia. Batang Arau river basin is located in the West Sumatra province, which is one of the areas that often experience the flood. Since 1894, a number of measures have been taken to control flooding in the Batang Arau river basin. However, until now, the incidence of flooding is still not appropriately resolved. The aim of this study is to identify the areas that had the worst impact due to flood events in the Batang Arau river basin over the past 10 years and then identify the leading causes of the flood event. After that, the Decision Support System (DSS) was carried out using the Analytical Hierarchy Process (AHP) method to determine the suitable measures both structural and no structural for flood control in the Batang Arau. In order to achieve these objectives, data was taken in the form of; the historical flood event over past 10 years, the factors causing flood events based on field observations and review studies, and Measures to control flood events according to experts. So that the results of this study will be able to describe short-term and long-term for flood management, which are adaptable for future flood management strategy.
\end{abstract}

\section{Introduction}

Batang Arau river, West Sumatra is one of the most flood-prone areas. It can be seen on the following map, which Fig.s out the new situation in the Batang Arau river basin and other river basins in Padang city. The factors which can cause flooding in this basin, are not only due to heavy rains, but also triggered by increasing the population growth, the climate, and the land-use change and others. However, this combination of factors leads to flooding occurs.

Batang Arau river basin has an area of $174.5 \mathrm{~km}$ square. Geographically, the Batang Arau river basin is located at $0^{\circ} 48$ "- $^{\circ} 56^{\prime \prime}$ LS and $100^{\circ} 21$ "- $100^{\circ} 33^{\prime \prime}$ BT with elevations from $0-1,210 \mathrm{~m}$ above sea level. The upstream part is in Lubuk Kilangan Subdistrict. Geographically, Lubuk Kilangan Subdistrict is located between $0^{\circ} 58^{\prime} 4^{\prime \prime} \mathrm{LS}$ and $100^{\circ} 21$ ' 11 " East Longitude, altitude $25-1,853 \mathrm{~m}$ above sea level, with an area of $85.99 \mathrm{~km} 2$. Air temperature ranges from $24^{\circ} \mathrm{C}-31.5^{\circ} \mathrm{C}$ with humidity ranging from $50 \%-75 \%$. Batang Arau River has a river length of $\pm 29.72 \mathrm{~km}$ from upstream to downstream. Batang Arau topography is dominated by steep to very steep slopes. This is because the degree of slope of the river basin slopes is getting more upstream, so the surface water flow velocity will be higher towards the river basins. The Batang Arau river basin is slightly oval in shape. The upstream river basin of the Batang Arau river basin is similar to the bird feather pattern, which means that water flowing from the tributaries enters the main river, but the flood discharge is small because the time of arrival of the streams varies.

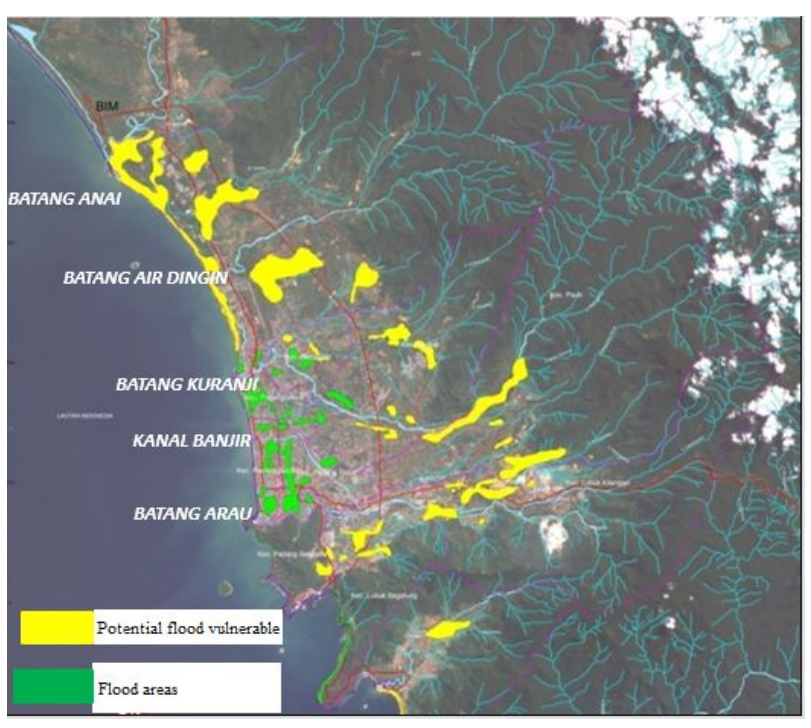

Fig. 1. Flood vulnerable areas.

On last November $2^{\text {nd }}, 2018$, there was a flash flood occurred in the Batang Arau river basin. It caused two fatalities, one bridge was broken, and one house was washed away, during heavy rain. This event was the worst event from the last 10 years, which create fatalities and damage in infrastructures. Based on this phenomena, the study is aimed to identify and analysis of Decision Support System using Analytical Hierarchy Process (AHP) method for integrated flood management in the Batang Arau river basin which can be implemented in the near future.

\footnotetext{
* Corresponding author: nurhamidah@eng.unand.ac.id
} 
This study aims to identify the worst affected areas of the flood along the Batang Arau river basin, to identify the causes of flooding that have threatened the Batang Arau river basin lately, to inventory current flood control and evaluate compliance with existing conditions, and to develop a flood measures strategy with the AHP decision making system.

The result of the research is beneficial as information and consideration for the Padang City government in planning the direction of spatial use, as information on flood disaster management models in the Batang Arau river basin and as information for future research.

\section{Decision Support System}

Decision Support System (DSS) is proposed to help the decision-makers in recognizing problems and then formulating supporting data for the purposes of problem analysis. The action taking DSS to facilitate one or all phases of decision making regarding the process runs effectively and efficiently (Sozer, Kocaman, Nefeslioglu, Firat, \& Gokceoglu, 2018). DSS is expected to assist management in decisions making strategic on flood management in the Batang Arau river basin.

A method that can be used as a supporter of DSS is the Analytical Hierarchy Process (AHP) method, where the AHP is a decision support model developed by Thomas L. Saaty (Saaty, 1990). This decision support model will describe multi-factor problems or complex multi-criteria into a hierarchy (Saaty \& Ergu, 2015). According to Saaty, hierarchy is defined as a representation of a complicated issue in a multi-level structure where the first level is a goal, followed by a factor level, criteria, sub-criteria, and on the last level of the alternative. With hierarchy, a complex problem can be broken down into groups which are then organized into a hierarchical form so that the problem will appear to be more structured and systematic. In the AHP method, the problem will be described in the form of a hierarchy as follows:

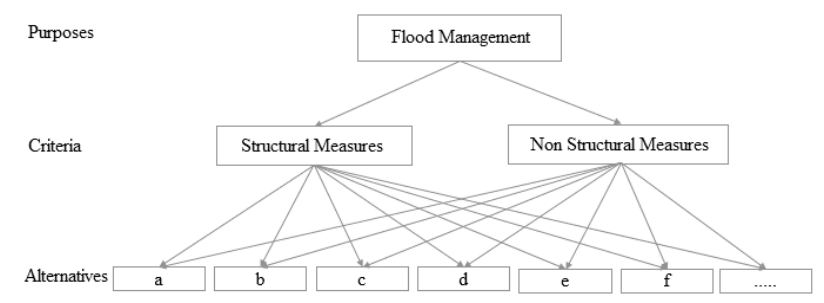

Fig. 1. Hierarchy AHP chart.

By using the decision-making system of the AHP method, a strategy that is a priority for the short-term and long-term floods will be obtained in the Batang Arau river basin. The steps in using the AHP method are as follows (Kadarsah Suryadi, Ali Ramdani, 1998; Aznur, 2017):

1. Defining the Problem. In this stage, it was tried to determine the problem that will be solved clearly, in detail, and easily understood. From the problem, it was attempted to establish a solution that might be suitable for the challenge. Solutions for issues could be more than one. Furthermore, it will be developed these solutions for the next stage.

2. Making a hierarchical structure. After arranging the main goal as the top level, a hierarchy level will be organized below that which is the appropriate criteria to consider or assess the alternatives it is provided and determined the other options. Each approach has a different intensity. The hierarchy is followed by subcriteria (if possible).

3. Create a Pairwise Comparison Matrix. The advantage of the AHP method is its ability to combine qualitative and quantitative elements. Quantitative things that are qualitative in nature are carried out by providing a perception of comparison scaled in pairs (pairwise comparisons scale). A person who will deliver these perceptions must understand thoroughly the elements that are compared and their relevance to the intended purpose.

According to Saaty, the scale of the comparison can be seen in the following table:

Table 1. Comparison Scale According to Saaty

\begin{tabular}{ll}
\hline $\begin{array}{l}\text { Intensity } \\
\text { of Interest }\end{array}$ & \multicolumn{1}{c}{ Information } \\
\hline 1 & $\begin{array}{l}\text { Both elements are equally important. Two factors have } \\
\text { the same effect }\end{array}$ \\
\hline 3 & $\begin{array}{l}\text { One element is a little more important than the other } \\
\text { aspects, Experience and judgment support a single part } \\
\text { slightly compared to the other elements }\end{array}$ \\
\hline 5 & $\begin{array}{l}\text { One element is more important than the other, Experience } \\
\text { and judgment actively support one aspect compared to the } \\
\text { other }\end{array}$ \\
\hline 7 & $\begin{array}{l}\text { One element is clearly more important than other factors, } \\
\text { one strong factor that is supported and dominant is seen in } \\
\text { practice }\end{array}$ \\
\hline 9 & $\begin{array}{l}\text { One element is absolutely essential than the other aspects, } \\
\text { Evidence that supports one issue against another has the } \\
\text { highest degree of affirmation that might strengthen }\end{array}$ \\
\hline $2,4,6,8$ & $\begin{array}{l}\text { Values between two values are contiguous considerations; } \\
\text { This value is given if there are two compromises between } \\
\text { the 2 reverse choices = If for the activity i get one number } \\
\text { compared to activity j, then } \mathrm{j} \text { has the opposite value } \\
\text { compared to i }\end{array}$ \\
\hline
\end{tabular}

\section{Calculation of Element Weight}

The calculation process is done using a paired matrix, as seen in table 2 . Filling $a_{12}$ values uses the following rules:

- If $\mathrm{a}_{12}=\alpha$, then $\mathrm{a}_{21}=1 / \alpha$

- If between operating elements $A_{1}$ and $A_{2}$ have the same level of importance, the value of $\mathrm{a}_{12}=\mathrm{a}_{21}=1$.

- Value of $\mathrm{a}_{12}=1$ for $1=2$ (diagonal matrix has a value of 1).

Table 2. Preference comparison matrix

\begin{tabular}{|c|c|c|c|c|}
\hline & $\mathrm{A}_{1}$ & $\mathrm{~A}_{2}$ & $\ldots$ & $A_{n}$ \\
\hline $\mathrm{A}_{1}$ & 1 & $a_{12}$ & $\ldots$ & $\mathrm{a}_{1 \mathrm{n}}$ \\
\hline $\mathrm{A}_{2}$ & $1 / a_{12}$ & 1 & & $a_{2 n}$ \\
\hline$\ldots$. & $\ldots$ & $\ldots$ & 1 & $\ldots$ \\
\hline$A_{n}$ & $1 / a_{1 n}$ & $1 / a_{2 n}$ & $\ldots$ & 1 \\
\hline
\end{tabular}


Consistency and Priority Vector Calculations.

This calculation is analyzed using the following equation:

$$
C I=\frac{\lambda m a k s-n}{n-1}
$$

Where: $\max \lambda=$ maximum eigenvalue $\mathrm{N}=$ matrix size The Consistency Index (CI) in the equation written above is a random matrix with a rating scale of 9 ( 1 to 9 ) along with the opposite as a random index (RI). RI has the values specified in table 3 depending on the number of matrix sizes compared (Taylor, 1999)

Table 3. Random Index Value RI (Taylor,1999)

\begin{tabular}{|c|c|}
\hline Matrix & Index of Random/RI (Inconsistency) \\
\hline 2 & 0 \\
\hline 3 & 0.58 \\
\hline 4 & 0.9 \\
\hline 5 & 1.12 \\
\hline 6 & 1.24 \\
\hline 7 & 1.32 \\
\hline 8 & 1.41 \\
\hline 9 & 1.45 \\
\hline 10 & 1.49 \\
\hline
\end{tabular}

The comparison between $\mathrm{CI}$ and RI for a matrix is defined as a Consistency Ratio (CR), as the following equation:

$$
C R=\frac{C I}{R I}
$$

For the AHP model, a comparison matrix is accepted if the value of the consistency ratio is $<0,1$.

\section{Research Methodology}

The research methodology begins with the identification of problems according to determined data. Data collection is divided into two; primary data from questionnaires which filled out with direct interviews with respondents. This interview was conducted on two parties experts related to water disaster and management, and communities who are living in Baringin, Lubuk Kilangan Sub-district. Secondary data, data on flood events obtained different resources from the local and national governments (BAPPEDA, BWS, and PSDA), i.e., Rainfall, discharge, land use, map, historic flood event. The flood events were evaluated using suitable flood management indicators, and give the value on each sign as AHP essential reference. Primary data were taken from local societies who directly impacted by flood on

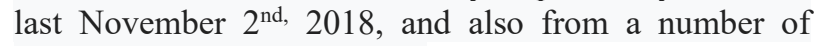
experts in flood management.

\section{Result and Discussion}

\subsection{Historical of flooding}

After collecting information from the number of resources, flood events along the Batang Arau river basin can be presented as follows in table 4 .

\begin{tabular}{|c|c|c|c|}
\hline No & Date & $\begin{array}{l}\text { Impacted areas } \\
\text { (district) }\end{array}$ & Damages \\
\hline 1 & $\begin{array}{l}\text { November } \\
2^{\text {nd }}, 2018\end{array}$ & $\begin{array}{l}\text { Lubuk Kilangan } \\
\text { Lubuk Begalung } \\
\text { Padang Selatan } \\
\text { Padang Timur } \\
\text { Padang Barat } \\
\text { Teluk Bayur }\end{array}$ & $\begin{array}{l}2 \text { bridges destroyed } \\
37 \text { houses inundated } \\
1 \text { fatality } \\
\text { Flood reach up to } 150 \mathrm{~cm}\end{array}$ \\
\hline 2 & $\begin{array}{l}\text { September } \\
26^{\text {th }}, 2018\end{array}$ & Padang Selatan & Flood reach up to $80 \mathrm{~cm}$ \\
\hline 3 & $\begin{array}{l}\text { September } \\
09^{\text {th }}, 2017\end{array}$ & $\begin{array}{l}\text { Lubuk Kilangan } \\
\text { Lubuk Begalung } \\
\text { Padang Selatan } \\
\text { Padang Timur } \\
\text { Padang Barat }\end{array}$ & Flood reach up to $60 \mathrm{~cm}$ \\
\hline 4 & $\begin{array}{l}\text { May } 31^{\text {st }} \\
2017\end{array}$ & $\begin{array}{l}\text { Lubuk Kilangan } \\
\text { Lubuk Begalung }\end{array}$ & $\begin{array}{l}2 \text { bridge destroyed } \\
\text { Landslide } \\
2 \text { houses destroyed } \\
\text { Cemetery destroyed } \\
200 \text { homes inundated }\end{array}$ \\
\hline 5 & $\begin{array}{l}\text { May } 21^{\text {st }} \\
2017\end{array}$ & Padang Selatan & $\begin{array}{l}6 \mathrm{sub} \text {-districts inundated } \\
\text { Flood reach up to } 150 \mathrm{~cm}\end{array}$ \\
\hline 6 & $\begin{array}{l}\text { June } 17^{\text {th }} \text {, } \\
2016\end{array}$ & $\begin{array}{l}\text { Lubuk Begalung } \\
\text { Padang Selatan } \\
\text { Padang Timur } \\
\text { Padang Barat } \\
\text { Teluk Bayur } \\
\end{array}$ & $\begin{array}{l}\text { Electricity destroyed } \\
\text { Flood reach up to } 140 \mathrm{~cm} \\
\text { Public services }\end{array}$ \\
\hline 7 & $\begin{array}{l}\text { November } \\
21^{\text {st }}, 2015\end{array}$ & Lubuk Begalung & Flood reach up to $100 \mathrm{~cm}$ \\
\hline 8 & $\begin{array}{l}\text { November } \\
12^{\text {th }}, 2015\end{array}$ & $\begin{array}{l}\text { Lubuk Kilangan } \\
\text { Lubuk Begalung } \\
\text { Padang Selatan } \\
\end{array}$ & $\begin{array}{l}92 \text { houses inundated } \\
1 \text { house destroyed by a } \\
\text { landslide }\end{array}$ \\
\hline 9 & $\begin{array}{l}\text { October } \\
19^{\text {th }}, 2013\end{array}$ & $\begin{array}{l}\text { Lubuk Kilangan } \\
\text { Lubuk Begalung } \\
\text { Padang Selatan } \\
\text { Padang Timur } \\
\text { Padang Barat }\end{array}$ & $\begin{array}{l}1500 \text { houses inundated } \\
\text { Flood reach up to } 150 \mathrm{~cm}\end{array}$ \\
\hline 10 & $\begin{array}{l}\text { July } 24^{\text {th }} \\
2012\end{array}$ & $\begin{array}{l}\text { Lubuk Kilangan } \\
\text { Lubuk Begalung }\end{array}$ & Flash flood and land slide \\
\hline 11 & $\begin{array}{l}\text { March } 26^{\text {th }}, \\
2010\end{array}$ & $\begin{array}{l}\text { Lubuk Begalung } \\
\text { Padang Timur }\end{array}$ & Flood reach up to $70 \mathrm{~cm}$ \\
\hline
\end{tabular}

Table 4. Historical flood events

According to the history of flood events from the last 15 years, the Batang Arau river basin belongs to the floodprone areas. Lubuk Kilangan is the most and frequent affected by flash floods. The flood caused, fatalities, injuries, destroyed of the public facilities, disturbed the public services including the local transportation. The worst situation has been found the highest level of flood reached up till $150 \mathrm{~cm}$. A number of structural and no structural measures have been taken to mitigate the flood risk. However, flood still occurs in almost every year.

\subsection{The causes of flood}

\section{Land use}

The land uses in Batang Arau river basin are classified into 6 such as forest, plantation, agriculture, land clearing including bushes, settlement, and mining. Identification of change in land use starts from 2000 until 2016. Based on the following table 5, a significant change has been found in the forest, from 5162 ha decrease to 3024 ha. Meanwhile, the settlement has a substantial change within 15 years from 42 ha increase 
to 3076 ha, plantation and agriculture also increase significantly.

Table 5. Changes in Arau Basin Land Use Code

\begin{tabular}{lrrrrr}
\hline \multirow{2}{*}{ Land uses } & \multicolumn{4}{c}{ Area (Ha) } & \multicolumn{1}{c}{$\begin{array}{c}\text { Total } \\
\text { change, Ha }\end{array}$} \\
\cline { 2 - 6 } & 2000 & 2006 & 2009 & 2016 & \\
\hline Forest & 5162 & 4699 & 2462 & 3024 & -2138 \\
\hline Plantation & 346 & 724 & 5598 & 2262 & 1916 \\
\hline Agriculture & 305 & 266 & 1377 & 1990 & 1685 \\
\hline Land clearing & 83 & 191 & 21 & 194 & 111 \\
\hline Settlement & 42 & 86 & 2319 & 3076 & 3034 \\
\hline Mining & 170,6 & 181,8 & 106,4 & 189,2 & 18,6 \\
\hline
\end{tabular}

\subsection{Flood Measures}

By comparing the results of interviews and references from books (J. Kadoatie, 2005), the primary indicators are determined to be a factor for flood control. After matching the suitability of the control effort to the circumstances that occur, the data obtained are as follows:

Table 6. Flood Measures

\begin{tabular}{ll}
\hline No. & Measures \\
\hline $\mathrm{a}$ & Carry out emergency response evaluations \\
\hline $\mathrm{b}$ & $\begin{array}{l}\text { Record damage to facilities and infrastructure, water } \\
\text { resources, environmental destruction, loss of life, and } \\
\text { estimated losses incurred }\end{array}$ \\
\hline $\mathrm{c}$ & Plan and implement recovery programs \\
\hline $\mathrm{d}$ & $\begin{array}{l}\text { Evaluate flood characteristics for adjusting future flood } \\
\text { predictions }\end{array}$ \\
\hline $\mathrm{e}$ & Prioritized development implementation \\
\hline $\mathrm{f}$ & Widening and dredging of rivers \\
\hline $\mathrm{g}$ & Making flood control buildings \\
\hline $\mathrm{h}$ & Operation and maintenance of flood control buildings \\
\hline $\mathrm{i}$ & Review of forest management systems upstream and land use \\
\hline $\mathrm{j}$ & Throw garbage in its place \\
\hline $\mathrm{k}$ & Forest planting again \\
\hline $\mathrm{l}$ & Performs arrangements for areas around the river \\
\hline $\mathrm{m}$ & Mapping areas prone to flooding and landslides \\
\hline $\mathrm{n}$ & Training and education for the community are ready to flood \\
\hline $\mathrm{o}$ & Evaluate with local residents regarding flood events \\
\hline $\mathrm{p}$ & Prepare the evacuation process through education \\
\hline $\mathrm{q}$ & $\begin{array}{l}\text { Coordinate with the local area to plan the actions needed in } \\
\text { flood control }\end{array}$ \\
\hline &
\end{tabular}

Furthermore, based on the listed data, from the data on flood management for the short and long term is grouped again into structural and non-structural measures. After that, the weighting is carried out for each of them to determine the priority measures of each group using the AHP method. Which can be seen in the following table:

a. From the previous weighting data, we do the calculation of each paired matrix alternatively
Table 7. The paired matrix of short-term flood management based on the non-structural measure.

\begin{tabular}{|c|c|c|c|c|c|c|c|}
\hline & & $\mathrm{a}$ & $\mathrm{b}$ & $\mathrm{c}$ & $\mathrm{j}$ & $\mathrm{m}$ & $\mathrm{o}$ \\
\hline & & 6 & 5 & 8 & 4 & 9 & 7 \\
\hline $\mathrm{a}$ & 6 & $6 / 6$ & $6 / 5$ & $6 / 8$ & $6 / 4$ & $6 / 9$ & $6 / 7$ \\
\hline $\mathrm{b}$ & 5 & $5 / 6$ & $5 / 5$ & $5 / 8$ & $5 / 4$ & $5 / 9$ & $5 / 7$ \\
\hline $\mathrm{c}$ & 8 & $8 / 6$ & $8 / 5$ & $8 / 8$ & $8 / 4$ & $8 / 9$ & $8 / 7$ \\
\hline $\mathrm{j}$ & 4 & $4 / 6$ & $4 / 5$ & $4 / 8$ & $4 / 4$ & $4 / 9$ & $4 / 7$ \\
\hline $\mathrm{m}$ & 9 & $9 / 6$ & $9 / 5$ & $9 / 8$ & $9 / 4$ & $9 / 9$ & $9 / 7$ \\
\hline $\mathrm{o}$ & 7 & $7 / 6$ & $7 / 5$ & $7 / 8$ & $7 / 4$ & $7 / 9$ & $7 / 7$ \\
\hline
\end{tabular}

Table 8. The paired matrix of long-term flood management based on the non-structural measure.

\begin{tabular}{|c|c|c|c|c|c|c|c|c|c|}
\hline $\begin{array}{c}\text { Alterna } \\
\text {-tives }\end{array}$ & & $\mathrm{d}$ & $\mathrm{h}$ & $\mathrm{i}$ & $\mathrm{k}$ & $\mathrm{1}$ & $\mathrm{n}$ & $\mathrm{p}$ & $\mathrm{q}$ \\
\hline & $\begin{array}{c}\text { Weight } \\
\text { value }\end{array}$ & 8 & 2 & 6 & 1 & 7 & 5 & 7 & 9 \\
\hline $\mathrm{d}$ & 8 & 1,0 & 4,0 & 1,3 & 8,0 & 1,1 & 1,6 & 1,1 & 0,9 \\
\hline $\mathrm{h}$ & 2 & 0,3 & 1,0 & 0,3 & 2,0 & 0,3 & 0,4 & 0,3 & 0,2 \\
\hline $\mathrm{i}$ & 6 & 0,8 & 3,0 & 1,0 & 6,0 & 0,9 & 1,2 & 0,9 & 0,7 \\
\hline $\mathrm{k}$ & 1 & 0,1 & 0,5 & 0,2 & 1,0 & 0,1 & 0,2 & 0,1 & 0,1 \\
\hline $\mathrm{l}$ & 7 & 0,9 & 3,5 & 0,3 & 7,0 & 1,0 & 1,4 & 1,0 & 0,8 \\
\hline $\mathrm{n}$ & 5 & 0,6 & 2,5 & 0,8 & 5,0 & 0,7 & 1,0 & 0,7 & 0,6 \\
\hline $\mathrm{p}$ & 7 & 0,9 & 3,5 & 1,8 & 7,0 & 1,0 & 1,4 & 1,0 & 0,8 \\
\hline $\mathrm{q}$ & 9 & 1,1 & 4,5 & 1,5 & 9,0 & 1,3 & 1,8 & 1,3 & 1,0 \\
\hline \multicolumn{2}{|c}{ Total } & 5,6 & 23 & 6,7 & 45 & 6,4 & 9,0 & 6,4 & 5,0 \\
\hline
\end{tabular}

Table 9. The paired matrix of long-term flood management based on the structural measure.

\begin{tabular}{|c|c|c|c|}
\hline Alternatives & & $\mathrm{f}$ & $\mathrm{g}$ \\
\hline & Weight value & 3 & 4 \\
\hline $\mathrm{f}$ & 3 & 1,00 & 0,75 \\
\hline $\mathrm{g}$ & 4 & 1,33 & 1,00 \\
\hline \multicolumn{2}{|c|}{ Total } & 2,33 & 1,75 \\
\hline
\end{tabular}

b. Normalization Calculations and Average Normalization of the Criteria Matrix

Table 10. Normalization of short-term flood management based on the non-structural measure.

\begin{tabular}{|l|c|c|c|c|c|c|r|}
\hline $\begin{array}{c}\text { Alternative } \\
\text { Matrix }\end{array}$ & & & & & & & $\begin{array}{c}\text { Mean of } \\
\text { alternative } \\
\text { matrix }\end{array}$ \\
\hline & 0,6 & 0,2 & 0,2 & 0,2 & 0,2 & 0,2 & 0,15 \\
\hline & 0,1 & 0,1 & 0,1 & 0,1 & 0,1 & 0,1 & 0,13 \\
\hline & 0,2 & 0,2 & 0,2 & 0,2 & 0,2 & 0,2 & 0,21 \\
\hline & 0,1 & 0,1 & 0,1 & 0,1 & 0,1 & 0,1 & 0,10 \\
\hline & 0,2 & 0,2 & 0,2 & 0,2 & 0,2 & 0,2 & 0,23 \\
\hline & 0,2 & 0,2 & 0,2 & 0,2 & 0,2 & 0,2 & 0,18 \\
\hline or & 1,0 & 0,8 & 1,3 & 0,7 & 1,5 & 1,2 & \\
\hline & 0,2 & 0,1 & 0,2 & 0,1 & 0,2 & 0,2 & \\
\hline
\end{tabular}


Table 11 Normalization of long-term flood management based on the non-structural measure.

\begin{tabular}{|c|c|c|c|c|c|c|c|c|c|}
\hline $\begin{array}{l}\text { Alterna- } \\
\text { tive } \\
\text { Matrix }\end{array}$ & & & & & & & & & $\begin{array}{l}\text { Mean of } \\
\text { alternative } \\
\text { matrix }\end{array}$ \\
\hline & 0,2 & 0,2 & 0,2 & 0,2 & 0,2 & 0,2 & 0,2 & 0,2 & 0,16 \\
\hline & 0,0 & 0,0 & 0,1 & 0,0 & 0,0 & 0,0 & 0,0 & 0,0 & 0,1 \\
\hline & 0,1 & 0,1 & 0,2 & 0,1 & 0,1 & 0,1 & 0,1 & 0,1 & 0,14 \\
\hline & 0,0 & 0,0 & 0,0 & 0,0 & 0,0 & 0,0 & 0,0 & 0,0 & 0,02 \\
\hline & 0,2 & 0,2 & 0,1 & 0,2 & 0,2 & 0,2 & 0,2 & 0,2 & 0,14 \\
\hline & 0,1 & 0,1 & 0,1 & 0,1 & 0,1 & 0,1 & 0,1 & 0,1 & 0,11 \\
\hline & 0,2 & 0,2 & 0,2 & 0,2 & 0,2 & 0,2 & 0,1 & 0,2 & 0,16 \\
\hline & 0,2 & 0,2 & 0,2 & 0,2 & 0,2 & 0,2 & 0,2 & 0,2 & 0,20 \\
\hline or & 1,0 & 1,0 & 1,0 & 1,0 & 1,0 & 1,0 & 1,0 & 1,0 & \\
\hline & 0,2 & 0,1 & 0,1 & 0,0 & 0,1 & 0,1 & 0,2 & 0,2 & \\
\hline
\end{tabular}

Table 12 Normalization of long-term flood management based on the structural measure.

\begin{tabular}{|c|c|c|c|}
\hline $\begin{array}{c}\text { Alternative } \\
\text { matrix }\end{array}$ & & & $\begin{array}{l}\text { Mean of } \\
\text { Alternative } \\
\text { matrix }\end{array}$ \\
\hline & 0,43 & 0,43 & 0,43 \\
\hline & 0,57 & 0,57 & 0,57 \\
\hline or & 1,00 & 1,33 & \\
\hline & 0,43 & 0,57 & \\
\hline
\end{tabular}

\section{c. Consistency Value of Random Index (RI)}

In this discussion, a test of the highest concentration value is carried out in one matrix table, because if the method is the same, then the resulting consistency value will be the same. The following is the calculation of the value of consistency for short-term flood control in the form of non-structural handling.

- First, the weight values of each alternative are multiplied by the average normalized matrix

Table 13. The weight values of each alternative multiplied by the normalization matrix

\begin{tabular}{|c|c|c|c|c|c|c|c|}
\hline Alternative & $\mathrm{a}$ & $\mathrm{b}$ & $\mathrm{c}$ & $\mathrm{j}$ & $\mathrm{m}$ & $\mathrm{o}$ & Sum \\
\hline $\mathrm{a}$ & 0.15 & 0.18 & 0.11 & 0.23 & 0.1 & 0.13 & 0.90 \\
\hline $\mathrm{b}$ & 0.11 & 0.13 & 0.08 & 0.16 & 0.07 & 0.09 & 0.65 \\
\hline $\mathrm{c}$ & 0.28 & 0.34 & 0.21 & 0.42 & 0.19 & 0.24 & 1.67 \\
\hline $\mathrm{j}$ & 0.07 & 0.08 & 0.05 & 0.1 & 0.04 & 0.06 & 0.40 \\
\hline $\mathrm{m}$ & 0.35 & 0.41 & 0.26 & 0.52 & 0.23 & 0.3 & 2.06 \\
\hline $\mathrm{o}$ & 0.21 & 0.25 & 0.16 & 0.32 & 0.14 & 0.18 & 1.25 \\
\hline
\end{tabular}

- Calculate the value of consistency by comparing the amount with the average value of the alternative matrix normalization

Table 14. Consistency value

\begin{tabular}{|c|c|c|}
\hline Alternative & Weight of priority & Consistency value \\
\hline $\mathrm{a}$ & $0,90 / 0,15$ & 6.00 \\
\hline $\mathrm{b}$ & $0,65 / 0,13$ & 5.00 \\
\hline
\end{tabular}

\begin{tabular}{|c|c|c|}
\cline { 2 - 3 } $\mathrm{c}$ & $1,67 / 0,21$ & 7.95 \\
\hline $\mathrm{j}$ & $0,40 / 0,10$ & 4.00 \\
\hline $\mathrm{m}$ & $2,06 / 0,23$ & 8.96 \\
\hline $\mathrm{o}$ & $1,25 / 0,18$ & 6.94 \\
\hline \multicolumn{2}{|c|}{ Mean of consistency $(\lambda)$} & 6.48 \\
\hline
\end{tabular}

- Calculate the CI value

$$
\begin{aligned}
& C I=\frac{\lambda \text { maks }-n}{n-1} \\
& C I=\frac{6,46-6}{6-1} \\
& C I=0,096
\end{aligned}
$$

Calculate the $\mathrm{CR}$ value as Known $\mathrm{RI}=1,24$

$$
\begin{aligned}
& C R=\frac{C I}{R I} \\
& C R=\frac{0,096}{R 1,24} \\
& C R=0,03
\end{aligned}
$$

$0,08 \leq 0,1$ then a consistent value can be received so that the results of matrix normalization can be used.

If the value is consistent $>0.1$, it is necessary to do a reevaluation when performing a paired matrix calculation.

\section{d. Ranking of Flood management on Priority Scale}

Table 15. Priority scales for short-term flood management for non-structural measure

\begin{tabular}{|c|c|l|}
\hline Alternative & Weight & \multicolumn{1}{|c|}{ Description } \\
\hline $\mathrm{m}$ & 0,23 & $\begin{array}{l}\text { Mapping areas prone to flooding and } \\
\text { landslides }\end{array}$ \\
\hline $\mathrm{c}$ & 0,21 & Plan and implement recovery programs \\
\hline $\mathrm{o}$ & 0,18 & $\begin{array}{l}\text { Evaluate with local residents regarding flood } \\
\text { events }\end{array}$ \\
\hline $\mathrm{a}$ & 0,15 & Carry out emergency response evaluations \\
\hline $\mathrm{b}$ & 0,13 & $\begin{array}{l}\text { Record damage to facilities and } \\
\text { infrastructure, water resources, } \\
\text { environmental destruction, loss of life, and } \\
\text { estimated losses incurred }\end{array}$ \\
\hline $\mathrm{j}$ & 0,10 & Throw garbage in its place \\
\hline
\end{tabular}

Table 16. Priority scales for long-term flood management for non-structural measure

\begin{tabular}{|c|c|l|}
\hline Alternative & Weight & \multicolumn{1}{|c|}{ Description } \\
\hline $\mathrm{q}$ & 0,20 & $\begin{array}{l}\text { Coordinate with the local area to plan the } \\
\text { actions needed in flood control }\end{array}$ \\
\hline $\mathrm{d}$ & 0,18 & $\begin{array}{l}\text { Evaluate flood characteristics for adjusting } \\
\text { future flood predictions }\end{array}$ \\
\hline $\mathrm{p}$ & 0,16 & $\begin{array}{l}\text { Prepare the evacuation process through } \\
\text { education }\end{array}$ \\
\hline $\mathrm{i}$ & 0,14 & $\begin{array}{l}\text { Review of forest management systems } \\
\text { upstream and land use }\end{array}$ \\
\hline $\mathrm{l}$ & 0,14 & $\begin{array}{l}\text { Performs arrangements for areas around the } \\
\text { river }\end{array}$ \\
\hline $\mathrm{n}$ & 0,11 & $\begin{array}{l}\text { Training and education for the community } \\
\text { are ready to flood }\end{array}$ \\
\hline $\mathrm{h}$ & 0,05 & $\begin{array}{l}\text { Operation and maintenance of flood control } \\
\text { buildings }\end{array}$ \\
\hline $\mathrm{k}$ & 0,02 & Forest planting again \\
\hline
\end{tabular}


Table 17. Priority scales for long-term flood management for structural measure

\begin{tabular}{|c|c|l|}
\hline Alternative & Weight & \multicolumn{1}{c|}{ Description } \\
\hline $\mathrm{g}$ & 0,57 & Making flood control buildings \\
\hline $\mathrm{f}$ & 0,43 & Widening and dredging of rivers \\
\hline
\end{tabular}

From each of the ranking results of the flood management on the priority scale, it can be seen that the priority of each flood measure is:

a. Priority scales for short-term flood management for non-structural action is to create the maps for floodprone areas and landslides

b. Priority scales for short flood management for the structural measure is the prioritized implementation of development

c. Priority scales for long-term flood management for the non-structural measure is to coordinate with the local area to plan the actions needed in flood control.

d. Priority scales for long-term flood management for the structural measure is to construct the flood protection buildings, e.g., dike

\section{Conclusion}

From the DSS study of the AHP method for management of the Batang Arau river basin, conclusions can be drawn as follows:

1. Based on flood events, it can be seen that the area along the Batang Arau river basin is prone to experiencing flood events. However, the Lubuk Kilangan area became the most affected area of floods in the last 10 years, with a total of 5 flood events and losses of broken bridges due to 3 floods.

2. The results of the analysis of land use data in the Batang Arau river basin area, it can be seen that the most significant land change occurred in the decrease in the field of Forest land by $-2137.60 \mathrm{Ha}$. From the calculation of the 10-year return period flood discharge, the Q10 value is $768.94 \mathrm{~m}^{3} / \mathrm{s}$. Meanwhile, based on the data on November 02, 2018, the flood discharge that occurred has exceeded the $\mathrm{Q}_{10}$ discharge rate, $\mathrm{Q}=1421,8 \mathrm{~m}^{3} / \mathrm{s}$.

3. Based on the existing flood control, there were 17 indicators been chosen as the priority for controlling the Batang Arau river basin against floods, which was then grouped based on short-term and long-term periods.
4. After conducting the DSS analysis using the AHP method, it is known that in the short term flood control, which is a priority in non-structural measures, it is a mapping of areas prone to flooding and landslides with a weighting of $23 \%$. Whereas in the structural action, there is only one indicator that becomes a priority, i.e., the implementation of priority development. Then the priority for the longterm period of non-structural is coordination with the local area to plan the actions needed in flood control with a weighting of $20 \%$, and non-structural handling is to create a flood protection building with an exciting weight of $57 \%$.

\section{Reference}

1. T. L. Saaty. What is the analytic hierarchy process?. pp. 109-121. Springer, Berlin, Heidelberg. (1988).

2. A. Aznur. Metoda AHP Pada Daerah Irigasi (2017).

3. P. Ella Yulaelawati. Mencerdasi Bencana. (2008).

4. M.B Goza. Analytical Hierarchy Process, 8,1 (2016).

5. R.J. Kodoati, \&R. Sjarief. Pengelolaan sumber daya air terpadu. (2005).

6. A. Junaidi, N. Nurhamidah. IJCIET, 1210-1219 (2017).

7. A. Junaidi, Nurhamidah, D. Darwizal, Future Flood Management Strategies. ICDM. (2018).

8. D. Legono. Decision Support System Mitigasi Bencana Banjir. Media Teknik (2003).

9. H. Listiyawati. Jurnal UGM (2010).

10. N. Nurhamidah, B. Rusman. International Journal of Civil Engineering and Technology, 966-978. (2017).

11. N. Nurhamidah, A. Junaidi,M. Kurniawan, Jurnal Rekayasa Sipil (JRS-Unand), 14,2, 131-138. (2018).

12. B. Sozer, S. Kocaman, H. A. Nefeslioglu, O. Firat, C. Gokceoglu. Analytical Hierarchy Process MAHP. International Archives of the Photogrammetry. (2018).

13. T. L. Saaty. RWS publications (1990)

14. T. L. Saaty. Journal ofInformation Technology and Desicion Making. 14, 6. 1171-1187. (2015)

15. C. Luu, J. Von Meding, and S. Kanjanabootra. Natural Hazards, 90,3. 1031-1050 (2018). 